\title{
Foreign Language Learning Recounts by Two Muslim Religious Scholars: A Narrative Education Discourse Analysis
}

\author{
Antar S. Abdellah \\ Qena Faculty of Education, South Valley University, Egypt
}

\begin{abstract}
The study analyzes two narratives written by Muslim religious scholars describing their experiences in learning a foreign language. Imam Mohammad Abduh's account on learning French and Sheikh Salman Al Ouda's account on learning English are the subject of analysis. These two scholars were selected because they represent two different cultures (Liberal Egyptian and conservative Saudi), two different ages (end of the $19^{\text {th }}$ century and end of the $20^{\text {th }}$ century) and two different language learning strategies (learning French and learning English). They were also selected because they are the ones whom are known to have written their experiences with learning a foreign language; Abduh through his student Rashid Reda in 1935, and Ouda by himself in his autobiography published 2011. The study analyzes these narratives and draws on literature from modern Educational theories in language learning and applied linguistics. Based on this analysis, the mentality of the Muslim religious scholars is unlocked with respect to foreign language learning. Differences and similarities between the two scholars' experiences are sorted out and implications for designing an ESP course based on these successful strategies are then proposed for similar religious scholars who wish to learn a foreign language.
\end{abstract}

Index Terms - learning strategies, Islamic education, religious scholars, EFL narratives

\section{INTRODUCTION}

The twentieth century witnessed the beginning of an age of enlightenment in both religious thought and civil movement. This movement was led by Jamal Eddin Al Afaghani who was followed by Mohammad Abduh, best known as Al Ustaz Al Imam. Abduh is considered a landmark in the modern Egyptian and Arab history. Away from his controversial religious views that aroused, and still arouse to this day, many disputes in both secular and religious societies, the man was distinguished in another field that was rarely treaded by religious scholars at his time; namely the field of foreign language learning. While Abduh who died in 1905 had a very special experience in learning the French language, the Saudi Muslim preacher and Scholar Salman Al Ouda followed Abduh's steps approaching the English Language. Both scholars are classified under the moderate school of Islamic thought. While Abduh is seen as a leader and one of the early godfathers who established modern Islamic thought, Al Ouda is an acting example of these thoughts that emerged from a very conservative environment and succeeded in making a difference in the religious as well as literary lives of many Muslim young people in the Arab world. A close reading of both scholars' experience is expected to achieve the following aims:

1- Identifying the psychology of learning and learning styles of religious scholars as reflected in their writings.

2- Tracing the learning strategies employed by these learners-scholars as represented in their narratives to reach a holistic view of their foreign language study.

3- Identifying aspects of self-study strategies that can be used individually by Higher Education students especially in a foreign context.

4- Comparing the experiences of two Muslim religious scholars who represent two different cultures wide apart by more than one hundred years (Abduh died in 1905 and Al-Ouda wrote his account in 2010).

\section{CONTEXT OF THE STUDY}

\section{Questions of the study:}

Based on the above introduction, the following are the questions of the study:

1- What are the strategies used by Muslim religious scholars in learning a foreign language?

2- In what way do these strategies represent modern education theories in foreign language learning?

3- What are the similarities and differences between both scholars' experiences?

4- What are the implications that can be derived from these scholars' experiences in learning foreign languages in higher education institutions? 
Employed in this study are two methods of analysis. First, discourse analysis was used as the primary and central method of inquiry. Tracey (1998) states that "discourse analysis is the close study of talk (or text) in context...situated within an interpretive social science meta-theory that conceives of meanings as socially constructed" (p. 10). Second, several principles of narrative were used as grounding for conducting this analysis of storytelling. Gergen (1991: p. 161) describes the life story as a type of "account you might give if musing over how you got to be where you are" (as cited in Bollis-Pecci, 2000)

The procedures that were utilized in the present study are the following:

1- A short biographical note is given to each scholar to explore the factors that shaped his character and affected this thought.

2- The excerpt of each scholar's narrative account is presented in English translation, and original Arabic extracts for both accounts are in the appendix.

3- An analysis of each text is then presented in the light of modern education and applied Linguistics theories. An explanation is given of the cultural and traditional Arabic context allusions.

4- Similarities and differences between both scholars' accounts are then spotted.

5- Lessons learnt, implications and recommendations are presented for developing foreign language courses for Muslim preachers, sheikhs, scholars, Imams and Islamic studies students.

\section{DATA ANALYSIS}

\section{A. Imam Muhammad Abduh (1849-1905)}

\section{A biography note:}

Born in 1849 in Lower Egypt and educated at Al-Azhar Islamic University, Imam Muhammad Abduh is best known as a reformer and a philosopher. Under al-Afghani's influence, Abduh combined journalism, politics, and his own fascination in mystic spirituality. He believed that education was the best way to achieve this goal. Kügelgen (2009) mentions that Abduh founded a religious society and became president of a society for the revival of Arab. He travelled a great deal and met with European scholars in Cambridge and Oxford. He studied French law and read a great many European and Arab works in the libraries of Vienna and Berlin. (as cited in Wikipedia, 2014).

Text:

"I started learning French when I was 44. However my inclination towards learning a foreign language was during the Urabi ${ }^{1}$ rebellion when I learnt the alphabet but I didn't use it and almost forgot it. When I first travelled to France, I stayed ten months editing issues of Al Urwa Al Wuthqa ${ }^{2}$ (The firmest bond) and I learnt nothing from French because my time with Assayed Jamal Eddin ${ }^{3}$ and Arab companions and my engagement in editing this journal didn't allow me to a have a sufficient time to start a systemic study. So this time was spent useless in learning the language. When I returned from exile to Egypt and after working in the national court and giving verdicts in criminal cases based on the French law and sitting among judges who were well-versed in this language, I had an urging tendency towards learning French so as not to be inferior in knowing laws to those with whom I sit in the law counsels. After I came to Cairo and worked in one of its courts, I found time and circumstances suitable to start work (in language learning).

I searched for a tutor and found a rather good one. So I invited him home, he came with a book of Grammar (Grammaire). I asked: what is this? He said: a grammar book. I said to him: "I do not have time to start, I rather have time to finish" then I handed him a novel by Alexandre Dumas, and said "I will read and you fix my pronunciation, and explain the (general) meaning. Anything except this is my duty and grammar will come along during work". In this manner I finished the book, and another and another. I was reading aloud whenever I was alone at home, so I learned the basics of French and could read and understand. However I couldn't speak (well).

After that I travelled to France and Switzerland many times during the summer vacations. I attended summer classes in Genève College. In this way I learnt French in my leisure time while I was working in jurisdiction in the Municipal Courts and the Courts of appeal. What really increased my lingering for learning a foreign language is that $I$ found that nobody can claim to have learning that can be used to serve the nation and to defend its interests as should be unless he knows a European language- why not? The interests of Muslims have become intertwined with the interests of the Europeans in all over the world. Can he, who does not know their

\footnotetext{
${ }^{1}$ Ahmad Urabi (1841-1911) was an Egyptian army general, and nationalist who led a revolt in 1879 against Tewfik Pasha, the Khedive of Egypt and Sudan, and the increasing European domination of the country. The revolt was ultimately crushed in 1882 when the United Kingdom invaded at the request of Tewfik, thereby commencing the 74 year British occupation Egypt. Urabi was the first Egyptian national political and military leader to rise from the fellahin. (Wikipedia, 2014).

${ }^{2}$ Edited from Paris by Jamal al-Din al-Afghani and Muhammad Abduh, al-Urwa al-Wuthqa was published between March and October 1884. The title, meaning "the firmest bond," alludes to the Qur $\square$ an; it had been used by Afghani in 1883 to refer to the pan-Islamic caliphate of the Ottoman sultan. After eighteen issues had appeared in 1884, the paper suddenly ceased publication, probably owing to lack of funds. Subsidization afforded wide distribution, which helped to enhance the reputation of the paper and its editors.

${ }^{3}$ Jamal al-Din al-Afghani (1838-1897), was a political activist and Islamic ideologist in the Muslim world during the late 19th century, particularly in the Middle East, South Asia and Europe. One of the founders of Islamic modernism and an advocate of pan-Islamic unity, he has been described as "less interested in theology than he was in organizing a Muslim response to Western pressure." (Ludwig, 2001, p. 32).
} 
language, then benefit from the goodness of their good (people) or get rid of the evil of their evil (people)? (Reda, 2003, pp. 104-105)

\section{Analysis:}

The first thing we notice in Abduh's account is that it is too short. He does not mention a lot of details but gives a rather reflective experience more than a detailed account. However short the account, it is heavy loaded with educational practices that represent modern language learning theories. The second thing to observe is his relatively old age (44) when starting to learn French, a thing that defies a negative attitude widely spread among young Muslim scholars.

We notice that the real urge for Abduh to start learning French was his work in jurisdiction. The best results of language learning are achieved when the purposes of learning are closely related to a learner's interest and work. Gardner and Lambert (1972 as cited in Hussin et al, 2001) introduced the notions of instrumental and integrative motivation. Instrumental motivation refers to the learner's desire to learn a language for utilitarian purposes (such as employment or travel or exam purposes) in the context of language learning. On the other hand, integrative motivation refers to the desire to learn a language to integrate successfully into the target language community.

What strikes attention is Abduh's discard of traditional grammar books that were very popular at his time, and his adoption of a content-based approach. At the time of Imam Mohammad Abduh, there was one dominant method of teaching foreign languages, namely the grammar-translation method. Thanasoulas (2010) states that: 'In the 17th, 18th and 19th centuries, foreign language learning was associated with the learning of Latin and Greek, both supposed to promote their speakers' intellectuality. At the time, it was of vital importance to focus on grammatical rules, syntactic structures, along with rote memorization of vocabulary and translation of literary texts'.

A look at English language courses used in Egypt by the end of the $19^{\text {th }}$ century ${ }^{4}$ shows that even in formal schooling, the grammar-translation method was overwhelmingly shaping the curricula. So to have Abduh discard of these prevalent teaching methodologies and current language courses is really a sign preceding his age.

Abduh, furthermore, indicates to the tutor his own personal method of teaching. This method compiles content-based instruction using literature as the core content, active learning strategies with Abduh doing most of the tasks, and the learning contract by identifying the roles of the tutor and the roles of the learner. Content-based Instruction (CBI), in Richards and Rodgers' words 'refers to an approach to second language teaching in which teaching is organized around the content or information that students will acquire, rather than around a linguistic or other type of syllabus...' (2005, pp 204, 207). It is worth noting that CBI as a systemic approach to language teaching and learning was not popular till the 1980s, and 'it is now widely used in K-12 programs for ESL students, in university foreign language programs and in business and vocational courses in EFL settings' (Richards and Rodgers 2005, p. 219). 'Literature-based programs can lead to increased use of literature for independent reading and improved attitudes toward reading for students experiencing difficulty in learning' (Morrow 1992).

It is worth noting that the content selected by Abduh is a world masterpiece by Alxandre Dumas. Abduh seems aware of the nature of world literature masterpieces and the French ones in particular. He understands that the canon of a nation represents its utmost peak in its standard language and reflects its morals and identity. In addition to the novel selection, Abduh takes the burden of reading and unlocking the meaning, while the tutor is there just to correct and explain ambiguities. Active learning where the learner is actively involved in the process of discovering things by himself is a celebrated approach in learning these days. Active learning is an umbrella term that refers to several models of instruction that focus the responsibility of learning on learners. Bonwell and Eison (1991) popularized this approach to instruction. A variety of research studies since the 1990s, has promoted an important principle: Guidance early, and then practice later is suggested for the best results. Another term related to Active Learning is Learner Autonomy. The term 'learner autonomy' was first coined in 1981 by Henri Holec, the 'father' of learner autonomy. Holec (1981 as cited in Wikipedia 2013) explains that many definitions have since been given to the term, depending on the writer, the context, and the level of debate educators have come to. It has been considered as a personal human trait, as a political measure, or as an educational move. This is because autonomy is seen either (or both) as a means or as an end in education.

There is also the idea of a learning contract. Contract learning is, in essence, 'an alternative way of structuring a learning experience: It replaces a content plan with a process plan.' Knowles (1986, p. 39). Education has to be an active rather than a passive process. To be active, students must participate in the process of education and become more independent and responsible for their own learning. They must develop the skills of self-directed inquiry. (Codde, 2006).

'Grammar will come along during work'- this sentence summarizes an abundance of language teaching research in grammar and grammar instruction. The Imam seems to refer to the functionality of grammar rather than the knowledge

\footnotetext{
${ }^{4}$ Examples include: Al Bakurah Al Shahyya Fi Nahw Al Lughah Al Injelizya (literally: the sweet first fruits in the English language grammar), but known as "English-Arabic Grammar" by Ahmad Faris Effendi in 1836, Al Muhawarah Al Inssyah Fi Al Lughatain Al Inkelizya wa Al Arabya (literally: the Human conversations in the English and Arabic languages), also known as "Arabic and English Grammatical exercises and Familiar dialogues) by the same author in 1840, Al Touhfa Al Baheyah Fi Al Lughatain Al Inkelizya wa Al Arabya (literally: the shining gift in English and Arabic), but known as "English-Arabic phrasebook" by Mohammad Lotphy and Hassan Hassanin in 1874, and Al Touhfa Al Baheyah Fi Al Lughaat Al Inkelizya wa Al Arabya wa Al Fransaweeyah wa Al Turkyyah (literally: the shining gift in English, Arabic, French and Turkish) by Mouhammed Mihri in 1899.
} 
about grammar. He focuses on grammaring rather than grammar itself. Larsen-Freeman's book 'Teaching Language; from Grammar to Grammaring' while recently published (2003), still proposes a chock for many teachers of a foreign language worldwide. Dickey (2004) expresses his astonishment wondering 'How do you review a book that calls for dramatic change in a traditional and key aspect of your profession?' Larsen-Freeman claims grammaring is 'the fifth skill'; the ability to use grammar structures accurately, meaningfully, and appropriately. Dickey, furthermore, sees Freeman's attempt on introducing grammaring to have 'some new and scary stuff in here. Teachers who are known as grammarians might be very uncomfortable with the message - teaching rules is not enough'. We can imagine that Abduh's tutor was equally scared not to teach grammar. Savignon (1983, p. 47) tells us the example of Montaigne who learnt Latin 'without methods, without a book, without grammar rules, without a whip and without tears'

Finishing more than one book (French novels) refers to a common trend in reading instruction known as 'extensive reading'. Pring (2011) sees that extensive reading is an approach to language learning, including foreign language learning, by the means of a large amount of reading. The learners view and review of unknown words in specific context will allow the learner to infer the word's meaning, and thus to learn unknown words. The idea behind extensive reading is that a lot of reading of interesting material that is slightly below, at, or barely above the full comprehension level of the reader will foster improved language skills.

While Abduh mentions French fictional works in this account, we have evidence from other writings that shows that he moved from extensively reading fiction to reading non fictional works. Reda (2006, p. 103) states that the Imam 'was very concerned about [reading] in Ethics, psychology, sociology, history, philosophy and education books. ... Rarely did he hear about a foreign book about Islam and Muslims and he didn't get a copy of it and read it.'

In addition to being an example of extensive reading practice, Abduh's choice of the French novels represents a selection of authentic learning materials. Harmer (1991) defines authentic texts as materials which are designed for native speakers; they are real texts; designed not for language students, but for the speakers of the language. Jordan (1997, p. 113) refers to authentic texts as texts that are not written for language teaching purposes.

Abduh used to read aloud when alone at home. This technique reflects the reading-aloud protocol. Katalin (2000) views reading in a second language as a problem-solving activity per se, because it involves considerable efforts on the reader's part to make sense of a text written in an unfamiliar code. Thus the cognitive processing required to comprehend a text written in a foreign language can easily become the subject of verbalization in a think-aloud experiment. This method of thinking and reading aloud has been used since the 1980s as a metacognitive strategy where a learner is aware of his learning procedures. It has since been used in language teaching, and other problem solving domains. Kussmaul and Tirkkonen-Condit (1995, p. 179) state the steps taken in this monologue protocol when translating; 'one subject talks to himself or herself while translating a text. Since talking to oneself is normally not a natural thing to do, the subjects are given a chance to get used to this behavior in a 'warming-up phase.'

Abduh's final comment on his experience affirms the moral purpose to which all his efforts are geared and from which all his innovative ideas stem. This moral purpose is defending the religion, spreading the word of God, and confronting the enemies of the nation. He has a high aim, a deep intrinsic motivation and high aspirations. It is not striking then that Michael Fullan's celebrated model of change is built upon the idea of a moral purpose. Fullan (2007, p 3) defines a moral purpose as 'acting with the intention of making a positive difference in the (social) environment...moral purpose is the only way for large scale, sustainable reform to occur — and it is moral purpose of the highest order. Moral purpose, however, without understanding of the change process is moral martyrdom. Having innovative ideas, and being good at the change process, is not the same thing.' Imam Muhammad Abduh represents a good model of a moral purpose accompanied with a deep understanding of change in his time. His high spirit is evident not only in learning a foreign language but, moreover, in learning a dead script within the study of grammatology. Reda (2006, p. 103) points out that the Imam 'learnt the [Arabic pre-Islamic script type called] Al Musnad because he knew that some European libraries hold some ruins of the Himyaritic kingdom [in which some inscriptions were written] which shed light on the history of Arabs and Islam'

\section{B. Sheikh Salman Al Ouda (1955- )}

\section{A biography note:}

Al-Ouda was born in 1955 in al-Basr, near the city of Burayda in Al-Qassim in central Saudi Arabia. He spent his early years in al-Basr then moved to Burayda. At the Burayda Institute, he studied Arabic grammar, Hanbali jurisprudence and hadith under the guidance of local sheikhs. He spent his early years in al-Basr and then moved to Buraydah to study. Al-Ouda was imprisoned for five years, from 1994 until the end of 1999 due to the anti-regime content of some of his books and some of the lessons that he had given. He was released along with his colleagues and resumed his activities from his home, giving lessons weekly. Al-Ouda has stated that he is currently supporting peace and coexistence with other religions. He announced that this was a result of deeper understanding of Islamic teachings. Al-Ouda is in charge of the popular website Islam Today, which offers a wide variety of subject matter and material. (Wikipedia, 2014)

Text (selected paragraphs)

When he started study in the academic institute, there was no real teaching of English. Despite his deep desire for religious education, he wanted to share public schools students' their distinction - so he enrolled as a part time student in the public intermediate school, and began to study some of its lessons. Nevertheless due to the 
parallel timing of both schools exams, he couldn't combine both types of study. In this way he missed the chance to gain the basics of the [English] language from an early time.

Even when English was established as a school subject in the academic institute, students didn't benefit from it; as the trouble makers in the class used to make strange noises when it was time for the English class ...the noise was unbearable. In addition to some whispering fatwahs issued by some sheikhs that allow cheating in the course of English! ...

[Learning] another language would give one a new linguistic system, a new thinking style...through which one can develop communication techniques; as language arts are the international train to ride for a wider and a bigger audience.

[Years later] Abul Munzir, who was a graduate of the British educational system, was leading the Zuhur prayer, when he looked back and rather than saying in Arabic "Sudu-l furaj", he said, in a rather quiet and sad voice, "close the gap, please". People preparing for the prayer smiled, while he [Ouda] found a thread to hold to, to achieve his old dream...

The controversy between the American and the British accents ...resembles the historical controversy between the Koufa and the Basrah schools in Arabic grammar..... he [Ouda] stayed, however, unable to overcome his Qassimi accent, unable to spot the differences between his own and others' pronunciation. It was not easy for him to digest a pronunciation he was not familiar with.

His learning tools: After he was interested in what cans might hold inside, he became interested in their package covers. He used to carefully examine the English sentences and phrases written outside...trying to get them in context before he does his lessons assigned by the tutor. Then he could get a big number of school books with which he interacted without a guide and in which he wrote comments, questions and answers. In addition to some short stories which represent common human background ...like Sinbad, Arabian Nights, Cinderella, and the wolf and the lamb...here you have returned a young child reading fairy tales and comic books!.. He wondered, however, if Europeans didn't find in the Arabic culture but these fairy tales to transfer into English!

Then [these learning materials] developed to an English-Arabic digital dictionary with a machine voice .... He preferred to carry it everywhere... and still remembers it as a dear piece of memory. Then he got a small radio... and placed the lever on the BCC. "A Journey to the cenre of the Earth..., step by step, Time to speak, the story of the three brothers, the lost boy, Make your break, The news: special English..etc" [are some of the programmes he followed] as indicated in his private papers. ... He may translate some of the titles into Arabic and sometimes writes the English, their pronunciation, and their translations, not knowing why he would do so. He would listen, record appointments, write down words, and if the broadcasting is not clear would write a note "We have got nothing today!". He used to write what he didn't understand, then look up the pocket e-dictionary for it. He may write comments on some of the phrases like: "He drinks a bottle of wine" - I seek refuge in Allah from you and what you drink!.

This habit (writing comments, personal views and other information on the margins) reflects what Heritage book experts call "al tasweed = blackening - writing in black ink)...some of them may state "a book is not whitened $=$ understood clearly, until it is blackened $=$ commented on". ...He finished three notebooks with vocabulary items, their meanings, conjugations and etymologies written in crammed handwriting horizontally and vertically, derived from the broadcast, school books, short stories - all he considers as an important wealth, part of his personality and history, including anecdotes, stories, occasions, and comments. In this way a notebook becomes a comprehensive container of study, news, events, dates, appointments, wishes and even thoughts.

....He tried to write in Arabic funny poetry some of the English vocabulary items and their meanings...so he began to write what he hears from the broadcast in poetry...

His first lesson with the tutor ...was in 1418. His note book includes many explanations in the neat handwriting of Muahammad Al Hadhif (the tutor). These include: explanations on grammar, very much like a Al Ajroumiya ${ }^{5}$, training on writing Cool Alphabet...some [learners] are obsessed with finding English words of Arabic origin...clarifications on problems of tenses..., wise optimistic sayings which rip despair from the heart of a believer, like: Pass the storm in peace, make the world a better place if you can, give him the freedom, Allah defends the oppressed...

He insists on this matter [learning a foreign language]...since other scholars in the past could learn different languages like Imam Muhammad Abduh... ... [For him] science has no age, and his own supremacy in Arabic language and literature means that his linguistic ability is not bad, and that he is able to unlock [the English language] secrets aided with a strong will. Sitting on the desk, he write, tries, hesitates, makes mistakes, arouses laughter by his faulty pronunciation, wipes the board, does his homework... he has already been identified with the character of a schoolboy but this time he finds it more interesting.

Whenever he remembers "close the gap, please", he smiles and realizes that there are many gaps that need to be closed... he has to carry on aided with supplications to Allah.....For him, a language is...more important for

\footnotetext{
${ }^{5}$ A celebrated traditional Arabic text in grammar by Ibn Ajroum.
} 
preachers and cultural speakers, not only to give people [knowledge] but to take[knowledge] from them as wellit is a matter of mutual interaction... in order to narrow the gap between people and Islam- the religion of Allah. Analysis:

Al-Ouda wrote this account in the third person to eliminate the unintentional boastfulness that can come from repeating "I" many times What strikes us at first in Al-Ouda's account is his high motivation and persistent trials to learn the language from an early age. "Enrolling in a public school as a part time student" was a remark of this high spirit. Like Abduh, he has a moral purpose and an early realization that language is "the international train to ride for a wider and a bigger audience". And like Abduh, he starts a serious study of a foreign language, only when he is above 40 (in $1418 \mathrm{H}=1996$ ).

In Al-Ouda's account, a reference is made to some of the misconceptions associated with learning a foreign language; especially English by some Muslim Sheikhs. Allowing cheating in English reflects the vision of these sheikhs to English as an imperialistic language, the language of the invaders who occupied many countries of the Arab world and are still Americanizing the peoples of the religion. With the gulf war, and America's unjustified support for Israel, many Arab scholars would associate English as a language with the practices of the American administration. In this view, English is seen as a thread to the national identity, a language of disbelievers, and a waste of time (Al-Hajoori: 2011, para 2). One naïve way of facing this thread would be the negligence of such study and encouraging students not to take it seriously.

The real start of learning English was the connotations aroused from his tutor's sentence "close the gap, please". He took it to mean the gap in his knowledge, the gap in reaching other people of different tongues, and the gap in benefiting from the wealth of knowledge provided through a foreign language. Urged by this personal understanding, and recollecting his failure as a young boy to get a systemic study of English, Al-Ouda seizes the opportunity and embarks unto learning English.

A major language learning theory encountered in Al-Ouda's account is the role of L1 in L2 learning. L1 refers to the mother tongue and L2 refer to the second or foreign language. Methodologists have long called for a pure direct teaching of the foreign language with no interference from the mother tongue. However, Brown (2000, as cited in Nazary, 2008) claims that "first language can be a facilitating factor and not just an interfering factor". Schweers (1999, p. 7) encourages teachers to incorporate the native language into lessons to influence the classroom dynamics, and suggests that "starting with the L1 provides a sense of security and validates the learners' lived experiences, allowing them to express themselves". Similarities that exist between the mother tongue and the foreign language can lead to fruitful results and can motivate the learner to carry on in studying a language that does not seem stranger any longer. Excluding the students' L1 for the sake of maximizing students' exposure to the L2 is not necessarily productive (Dujmovic, 2007, as cited in Nazary, 2008). A large scale study by Levine (2003) in an ESL context revealed the same result. Levine concludes that "despite the prevailing monolingual principle in U.S FL classes, both the target language and the L1 appear to serve important functions" (p. 356).

Al-Ouda's use of L1 in learning L2 is evident in the similarities he jots down between Arabic and English, even if the similarities are sometimes funny and with no real linguistic value. Examples include resembling the American and the British accents to the Basrah and Koufa schools of Arabic Grammar, resembling the sounds of the word 'grammar" with the sounds of the celebrated traditional Arabic text on grammar called "Al Ajroumiya", and commenting on the obsession of some learners to search for Arabic origins of some English words.

Another important theory that is reflected in the account is "individualized learning". Reading cans covers, ads and signs is a practical practice of reading comprehension, it is visual learning and it is authentic materials use. Reading ingredients, advertisements and coupons is a great way to help students become confident and independent as they work through activities involving real-life situation. There are even some training courses in reading that are mainly based on reading ads and package covers (Boning 1978 and Remedia 2007). According to Daves et al (1996, p. 32) "Visual learners are those who learn primarily with their eyes. It is important for the teacher to use resources that must be read or seen: the chalkboard, posters, and bulletin boards; books, magazines, and manuals; programmed learning materials; drawings, pictures, graphs, and diagrams; films, filmstrips, transparencies, and computer monitors if available. Visual learners prefer to have written assignments, and it is wise for the teacher to provide written evaluations".

Like Abduh, Al-Ouda heads to literature, but rather than picking a full-text original novel, Al-Ouda selects some simplified readers largely based on Orientalists' view of the Arab culture. His autonomy is evident in collecting the old schoolbooks, short stories and comics used by children in different countries to undertake a serious study of these easyto-handle materials. Depending on West's supplementary readers for different levels paves the way for Al-Ouda to carry on in this internationally used language. In these endeavors, Al-Ouda reflects the literature-based, content-based and authentic materials and learner autonomy theories discussed above.

Moving to modern learning aids represents a development in the techniques of studying a foreign language for Muslim religious scholars. Using a digital dictionary and then a radio is one of the implementation of available technology in language learning. Research has repeatedly confirmed the effectiveness of such devices in developing language skills. Using pocket e-dictionaries has proved to be an effective language learning tool. While some educators insist on paper-based dictionaries (Koren 1997; Weschler \& Pitts 2000), Jian et (2009, p. 511) emphasize that if referencing a dictionary is a bottleneck in the language class, then the motivation for study and learning progress may 
be hindered. If the student is allowed to use an electronic pocket dictionary, the focus and effort can be shifted away from the mechanical and laborious task of referencing the dictionary onto the actual language learning.

In addition to the digital dictionary, Al-Ouda makes use of the radio programmes. Crookall (1983, p. 155) states that "radio broadcast can foster intercultural understanding". He (1983, p. 300) also notes that "...listening to other countries' media may contribute a little to greater awareness of the fact that different people perceive and interpret the world in different ways. Cross-cultural communication is an area of much study and of increasing concern among L2 teachers". The use of the BBC per se has also been reported to be highly effective in developing second and foreign language learners' skills in English. Rybak (1980) highlights the developments in the BBC pedagogy and presentational style of language programs and also discusses the progressive attempts to combat drop outs.

What is more important than using the radio programmes, is how Al-Ouda interacted with these programmes. We notice that he used not only to write down most of what he listens to, but also to write comments on it to make it easy to remember, and fun to recall. "Seeking refuge in Allah" when writing something on wine, is one example of the interaction he has with the process of language learning, in addition to the lengthy Arabic sentences he writes on news concerning the Arab or the Muslim world. This personalization style (linking situations to one's interests and real life with a critical consciousness) is a celebrated language learning and teaching strategy. Greater personalization requires greater participation and control over their learning in the decisions of learning.

The peak of Al-Ouda's personalization is embodied in his detailed comments on the margins of his notebook. This in turn is highly reflective learning; where learners reflect on their experiences in language learning and act as contributors to the process of learning. This is also known as the Experiential approach in learning. Experiences of language, communication, culture and personal learning processes are essential for foreign language learning - but they need to be processed consciously for learning to take place. Learning requires an explicit awareness and understanding of what it is that needs to be learned (metalinguistic and metacognitive awareness), and why such learning is necessary. Learning is the process of creating new knowledge and understandings through the transformation of experience. Reflection plays an important role in this process by providing a bridge between practical experience and theoretical conceptualization (Kolb 1984). Experiential learning involves observing the phenomenon and doing something meaningful with it through an active participation. It emphasizes learning in which the learner is directly in touch with the phenomenon being studied, rather than just watching it or reading, hearing or thinking about it (Kohonen 2001, as cited in Mollaei \& Rahnama, 2012).

Keeping a phrase notebook for recording new vocabulary items and unfamiliar expressions is another note of good attention paid to the study of a foreign language. Cramming these vocabulary notebooks with words, their meanings, their pronunciation, examples for their use, comments on similar words, etymologies, related Arabic sayings or lines of poetry- all incorporate the active learning experience. Educators have reported effective language learning results when aided with vocabulary and phrase notebooks. Vocabulary notebooks encouraged for use by EFL learners as a tool to aid them in their learning and achieve learning mastery (Fowle, 2002, Schmitt and Schmitt, 1995; Laufer and Nation, 1999). Among the 58 vocabulary learning strategies included in Schmitt's (1997) taxonomy, keeping a vocabulary notebook is classified as a cognitive strategy within the larger division of consolidation strategies. (Walters \&Bozkurt, 2009)

Writing Poetry that incorporates English vocabulary with Arabic meanings reflects a high level of musical intelligence affected by a long history of Arabic language tradition of forming difficult knowledge in sonorous rhymed lines of verses which resemble the heroic couplet technique in Neo-Classical English poetry to be easy for students to enjoy and memorize. The Multiple Intelligences theory proposed by Gardner in 1983 claims that humans have different separate types of intelligences rather than a single general ability. He identified eight types of intelligences; the linguistic, the logical, the bodily, the visual, the musical, the natural, the intrapersonal, and the interpersonal intelligences. Musical intelligence people have sensitivity to rhythm, rhyme, pitch, meter, tone, melody or timbre. Music and rhythm have been defined as powerful aids to language learning, memory, and recall.

Focusing on proverbs and wise sayings is in fact using common past experiences shared among different nations. A proverb is "a saying popularly known and repeated, usually expressing simply and concretely, though often metaphorically, a truth based on common sense or practical human experience. Dougall (2004) points out that the learning of proverbs can be a key element in the language acquisition process. 'Refrains, idioms, and proverbs can provide a snapshot of other cultures that allows for "a more thorough understanding of both language and culture". Leeven (2010) calls proverbs "language learning magic tools"; he states "even more magic awaits the language learner in the form of old-fashioned proverbs. Not only do they teach language but culture as well. Proverbs often embody what can be most pleasing about learning another language - a surprising change in perspective".

A final remark on Al-Ouda's experience is his high spirit, excessive work, and high motivation. All these are believed not to have continued with him in his imprisonment plight without aid from God. The spiritual factor cannot be undermined in the process of education and learning a foreign language in particular. Hong (2007, p. viii) conducted a qualitative study to investigate the effect of Spirituality and the Christian faith on the practices and paradigms of language teaching professionals and concluded that "the Christian faith permeates every aspect of Christian scholars' professional development including vision, motivation, problem-solution, decision making, and personal relationships with students". Al-Ouda's consistent supplication and deep faith in Allah acted as a helping factor that keeps motivation high, and will strong - the will to close the gap. 


\section{RESULTS AND DISCUSSION}

\section{Similarities and differences between the two accounts:}

While the two accounts were written in quite different circumstances and the two experiences are rather different, certain similarities can be noticed between them. Both Imams seem to have a high inclination towards learning a foreign language. Both started learning a foreign language when they were above 40 of age. Both consider language a universal medium for reaching wide groups of people worldwide. Both have a moral purpose to achieve; namely delivering the message of Islam as well as benefiting from other peoples' wisdom. Both rely on literature as the main content in their experience and both enjoy a high linguistic ability in the mother tongue. Both scholars seem quite autonomous in their learning and seem aware of their needs and their capabilities.

On the other hand, certain important differences are also noticed between the two accounts. While Abduh seems preceding his age and using $20^{\text {th }}$ century theories (like grammaring, CBI, authentic materials), Al-Ouda seems more influenced by his Arabic traditional culture (writing comments on the margins, forming new vocabulary in Arabic poetry, using proverbs). While Abduh seems to be in full command of his learning process that he directs the tutor to carry out certain roles, Al-Ouda seems more dependent on his tutor. While Abduh makes use of full text original novels written by French writers from the very first day, Al-Ouda resorts to simplified texts, mainly translations of Arabized fairy tales. Abduh seems to put very high levels for himself from the start, while Al-Ouda seems to go step by step in this new world, preferring to start from something he already knows to something new. While Abduh combined both reading- writing and listening-speaking in two different contexts (in Egypt and in Geneva), Al-Ouda had to depend mainly on reading and writing, and the only resource of listening would be his tutor and the BBC programmes. This limited access to the spoken language affected his speaking ability as he confesses he couldn't get rid of the Qassimi dialect. While Abduh discarded the traditional study of grammar from the start and focused on meaning, Al-Ouda had to write down pieces of grammatical rules and structural examples in his confidential notebooks. While Abduh set a duration for finishing his learning process from the start, Al-Ouda does not seem to have cared about finishing- may be because he didn't know when he would be released.

\section{Lessons learnt and Implications:}

\section{For language learners}

Language learners in general and Islamic studies students in particular, who want to learn a foreign language, are advised to consider the experiences of both scholars. Making use of the rich and varied strategies will facilitate learning and empower motivation to achieve high standards of language learning. Holding a moral purpose and working towards a spiritual higher goal is an effective and successful technique for carrying on the study of the foreign language.

\section{For language teachers}

Understanding the nature and needs of the learners should top the priorities of a successful language teacher. These needs are the key to effective learning and teaching. Teachers are advised to discover the learning styles and the preferences of their learners so as to design learning materials that are suitable for them. Teachers can make use of some of the techniques used in the two scholars' accounts in order to enrich the learning experience of their students.

\section{For language course designers}

Using general language courses with people of different backgrounds does not seem to be a wise decision. Developing an ESP course for Islamic studies, religiously inclined students, Muslim scholars, preachers and Imams, should take into consideration some of the features of the language learning experiences analyzed in this study. Such a course should address areas of interest and uses enriching supplementary materials for this group of learners.

\section{CONCLUSION}

While 100 years separate between Imam Muhammad Abduh and Sheikh Salman Al-Ouda, both of their experiences in learning a foreign language reflect different aspects of the Muslim religious mentality. Successful language learning strategies take place when there is an urging need to make it happen, when there is a moral purpose that keeps motivation high, and when there is a real desire to close the gap. 


\title{
TEXT ONE
}

\begin{abstract}
"بدأث بتعلم اللغة الفرنساوية عندما كانت سني أُريعا وأُريعيز سينة. ولكز ميلي إلى تعلم لغة أجنبية ابتدأ في أثناء الحوادث العرابية فتعلمث الهجاء ثم تركته

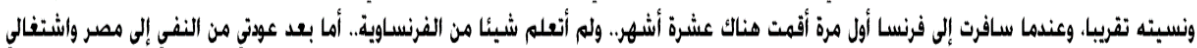

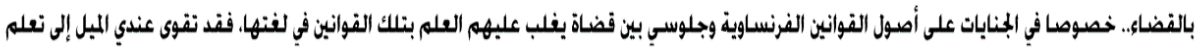

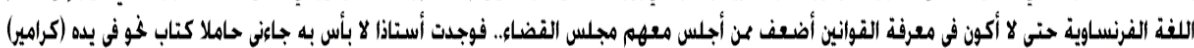

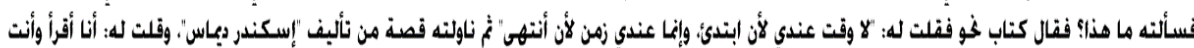

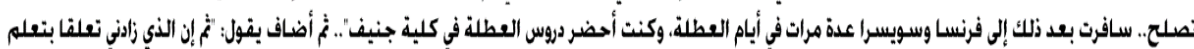

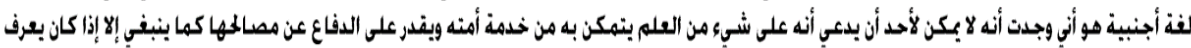

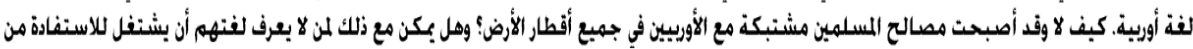
خبرهم للخغلاص من شر الشرار منهم"؟ب.
\end{abstract}

\section{TEXT TWO}

\begin{tabular}{|c|c|}
\hline 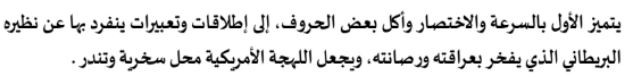 & 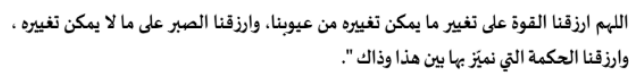 \\
\hline الليجة البريطانية تتميز بالراء العجيبة في آخر الكلمات، حيث تصبح ألفاً مفخمة .. والليجة & أعجبه هذا الدعاء وظلَ يردده، فانشغالاته صنعت ثغراتٍ طالما تمنى أن يسذّها، ونقائص طالما \\
\hline 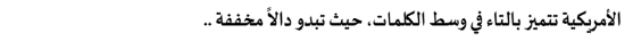 & 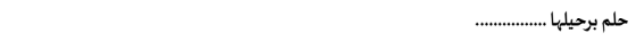 \\
\hline وبين التخفيف الأمريكي الذي كأنه يحدث رجل الشارع .. وبين الثقل البريطاني الذي كأنه مذيع في & -حين درس في المعهد العلمي لم يكن ثم تدريس للغة الإنجليزية ، ومع رغبته في العلم الشرعي ، \\
\hline 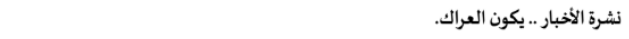 & أحب أن يشارك طلاب المدارس الأخرى تميّزهم ، واستطاع أن يسجل نفسه كمنتسب في \\
\hline أما هو فظل عاجزاً عن تجاوز ( الاكسنت القصيمي ) ، وعاجزاً عن تحديد نقاط الاختلاف بينه & المتوسطة العامة ، وأن يذاكر دروسها ، بيد أن وقوع الامتحان في ذات الوقت حرمه من الجمع \\
\hline وبين الاخرين ، وإن كان سمعله ينبو عن نطق لم يألفه. . & يين الدراستين ، وبذاك فاتت عليه فرصة التزود في الصغر من أساسيات هذه المادة. \\
\hline 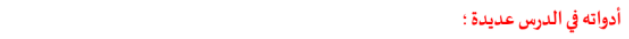 & وحتى بعد تقرير الممادة في المعاهد العلمية لم يتمكن الطلاب من الانتفاع بها. \\
\hline بعد أن كانت محتويات العُلَب هي التي تعنيه ، بدا له اهتمام جديد بملصقاتها الخارجية وأغلفتها & كان العابثون في الفصل - في معهد بريدة - يصدرون الأصوات الغرببة والجلجلة والصلصلة حين \\
\hline · إذ كان يتفحَص ما بُكتب عليها من العبارات الإنجليزية ، وبربطها بسياقها في محاولة للترجمة & يحين وقتها : فهي بالذات مادة إضحاك وعبث .. يستغلها الكبار المتلثمون القابعون في زاوبة \\
\hline 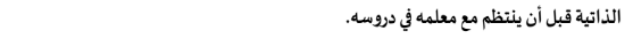 & الفصل حيث يديرون الفوضى ، إذا صح للفوضى أن تدار ، ويدبرون العبث إذا صح للعبث أن \\
\hline ثم ظفر بمجاميع من الكتب المدرسية، التي طليها من المكتبات، وتعاطى معيا بمفرده دون مرشد & يدبر .. فيفوت الطالب الجاد أن يعطي شيئًا من تركيزه على تلك المادة آنذاك .. فالفصل صخب \\
\hline أو دليل، وملأها بالتعليقات والإجابات والأسئلة، إضافة إلى قصص قصيرة هي من المشترك & لا يطاق! \\
\hline الثقافي البشري، إذ وجد نفسه يقرأ بلغة أخرى قصة السندباد، أو ألف ليلة وليلة، أو سندربلا ، & 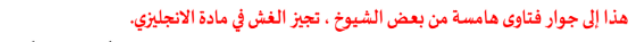 \\
\hline أو العنز والذئب!. & سبح خياله في تصوَر الفرص القائمة واصطيادها ، فلن تجد نفسك في وضع أفضل مما أنت \\
\hline ها قد عدت طفلأ تقرأ قصص الصغار ورسم الكارتون!. & عليه الآن: لتفكَّ رموز اللغة الأخرى ـ وتقتحم أسوارها ، وتستكشف أسرارها.. فاللغة الأخرى \\
\hline وعرف أن المرء كلما بدأ عالماً معرفياً جديداً بدأت طفولته وكبر صغره .. وعاد بكتب الدرس، & تعطيك نظاماً لغوياً وفكرياً جديدأ تفكر به وتعيشه وتطور مفاهيمك من خلاله وتطور آليات \\
\hline 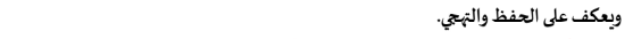 & الاتصال من خلاله فالمعارف اللغوية هي القطار العالمي للحديث إلى جمهور أكبر وأكثر والاستماع \\
\hline وعجب ألا يجد القوم من ثقافته العربية إلا هذه الأحدوثات لينقلوها. & إلهه. \\
\hline وحيث أنه كان يقرأ الكلمات نحتاً ،كان يظن أن بعض الأحداث لم تكن موجودة داخل النسخة & كان أبو المنذر يتقدميم يومأ في صلاة الظير ، وهو خريج المدرسة البريطانية في اللغة الإنجليزية، \\
\hline العربية للقصة. & التفت إلى المأمومين، وعوضاً عن "تراصَوا وسدوا الفُرج" قال بصوته الهادئ جداً، والحزين جداً \\
\hline ثم تطورت إلى جهاز معجم إنجليزي-عربي، بصوت آلي، تسلل إلى غرفته بطرقة خاصة، كان & "كلوز ذ قاب بليس"، تلقَف المأمومون ذلك بابتسامات بعددهم ، أما هو فكأنما مذَ إليه خيطاً \\
\hline بخبئه عند تركه الغرفة، إلا أنه لا يتخلص من القلق لتركه : ففضتّل أن بحمله في ذهابه وإيابه . & 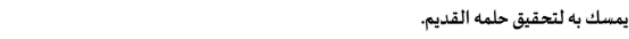 \\
\hline خشية أن يقع في أيدي مسؤولي التنظيف والرقابة، ولا يزال يحتفظ به كذكرى عزيزة على نفسه. & اختار بسعادة أن يعود تلميذاً ، واختار د. محمد الحضيف أستاذاً له. . . \\
\hline ثم توسعت دائرة الممنوعات إلى اقتناء المذياع، والذي أصبح موجوداً في أكثر الغرف، وتفنن & أن تكون تلميذاً من جديد ليس بالأمر الهين على النفس ، خاصة حين تبدأ من الألف باء ، على \\
\hline الناس في إخفائه، حتى تفتقت حيلة أحدهم عن حفر داخل كتاب ضخم، وإخفاء المذياع وسط & أن مما شد من أزره أنه لم يكن وحيدأ في الأمر ، فيناك الشيخ سفر الحوالي ومجموعته الذين \\
\hline صفحاته، ثم صفهّ بين الكتب بطريقة لا تخطر على بال الرقيب... & اختاروا د. محسن العواجي أستاذأ لهم ، وكان يسكن بجوارهم ، والدكتور محسن هو خريج \\
\hline لم يكن هو من المبادربن بهذه المغامرة غير محسوبة العواقب، حتى اقتربت أن تكون عرفاً جاربا & 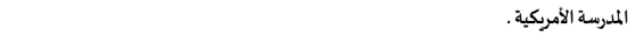 \\
\hline 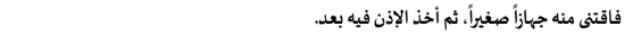 & العراك بين الاكسنت الأمركي ، ونظيره البريطاني على أشذَّه في حقول التعليم ، والأصحاب \\
\hline 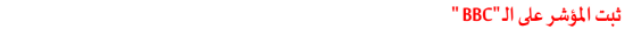 & شيهونه بالخلاف التاربخي بين مدرسة الكوفة ومدرسة البصرة في النحو العربي! \\
\hline
\end{tabular}

\section{REFERENCES}

[1] Ahmed 'Urabi. (2014, May 8). In Wikipedia, the Free Encyclopedia. Retrieved 20:26, May 21, 2014, from http://en.wikipedia.org/w/index.php?title=Ahmed_\%E2\%80\%98Urabi\&oldid=607700971.

[2] Al-Hajoori. Y. (2011). Shaikh Yahya's advice on teaching English. Retrieved October 12, 2009, from: http://aloloom.wordpress.com/2011/12/23/shaikh-yahyas-advice-on-teaching-english.

[3] Al-Ouda. S. (2010). Tofulat Qalb (The Infancy of a heart). Riyadh: Islam Today Foundation.

[4] Bollis-Pecci. T. (2000). A Narrative Discourse Analysis of a Midlife Woman's Story of Her Return to College. American Communication Journal. 2,(1), 141-151.

[5] Boning. R. (1978). Reading ads: programs for individualized instruction. Dexter \& Westbrook.

[6] Bonwell. C. \& Eison. J. (1991). Active Learning: Creating Excitement in the Classroom AEHE-ERIC Higher Education Report No. 1. Washington, D.C.: Jossey-Bass. 
[7] Codde. J. (2006). Using learning contracts in the college classroom. Online article. Retrieved May, 21, 2014 from: https://www.msu.edu/user/coddejos/contract.html.

[8] Crookall. D. (1983). Voices Out of the Air: World Communications Year, International Broadcasting and Foreign Language Learning. System, 11 (3), 295-302.

[9] Daves. E., Nur. H. and Ruru. S. (1996). Helping Teachers and Students Understand Learning Styles. English Teaching Forum.96. (2). 32-33.

[10] Dougall. D. (2004). Why learn Proverbs? Retrieved January 7, 2009, from: http://www.lingo24.com/articles/Why_Learn_Proverbs--7.html.

[11] Effendi. A. (1836). Al Bakurah Al Shahyya Fi Nahw Al Lughah Al Injelizya. Malta: Al Jawaeb printing

[12] Effendi. A. (1840). Al Muhawarah Al Inssyah Fi Al Lughatain Al Inkelizya wa Al Arabya. Malta: Al Jawaeb printing

[13] Fowle. C. (2002). Vocabulary notebooks: implementation and outcomes. English Language Teaching Journal, 56(4), $380-88$.

[14] Fullan. M. (2007). Leading in a culture of Change. San Francisco: Jossey-Bass

[15] Gardner. H. (1983) .Frames of Mind: The Theory of Multiple Intelligences. New York: Basic Books.

[16] Harmer. J. (1991). The Practice of English Language Teaching. London: Longman

[17] Hong. M. (2007). Spirituality and English Language Teaching- A Christian Exploration. PhD Dissertation. Purdue University, West Lafayette, Indiana.

[18] Hussin. S, Maarof. M, and D'Cruz. J. (2001). Sustaining an Interest in Learning English and Increasing the Motivation to Learn English: An Enrichment Program. The Internet TESL Journal, VII (5), http://iteslj.org/.

[19] Jian. H., Sandnes. F., Law. K., Huang. Y. \& Huang. M. (2009). The role of electronic pocket dictionaries as an English learning tool among Chinese students. Journal of Computer assisted language learning, 3 (25). 503-514.

[20] Jordan. R. (1997). English for Academic Purposes: A Guide and Resource for Teachers. Cambridge. Cambridge University Press.

[21] Katalin, E. (2000). 'Please, Keep Talking': The 'think-aloud' Method in Second Language Reading Research. Novelty, 7(3), 48-59.

[22] Knowles. S. (1986). Using Learning Contracts. San Francisco, CA: Jossey-Bass Inc., Publishers.

[23] Kohonen, V. (2001). Towards experiential foreign language education. In Kohonen, V., R. Jaatinen, P. Kaikkonen and J. Lehtovaara, Experiential learning in foreign language education. London: Pearson Education, 8-60

[24] Kolb. D. (1984). Experiential learning. Englewood Cliffs, NJ: Prentice Hall.

[25] Koren S. (1997) Quality versus convenience: comparison of modern, dictionaries from the researcher's, teacher's and learner's points of view. TESL-EJ 2. Retrieved September 7, 2012, from: http://tesl-ej.org/ej07/a2.html.

[26] Kügelgen, A. " $\square$ Abduh, Muḥ ammad." Encyclopedia of Islam, THREE. Edited by: Gudrun Krämer, Denis Matringe, John Nawas and Everett Rowson. Brill, 2009. Brill Online. Syracuse University.

[27] Kussmaul. P. and Tirkkonen-Condit. S.(1995). "Think-Aloud Protocol Analysis in Translation Studies". TTR : traduction, terminologie, rédaction, 8, (1), 177-199.

[28] Larsen-Freeman, D. (2000). Techniques and principles in language teaching. New York: Oxford University Press

[29] Larsen-Freeman. D. (2003). Teaching Language: from grammar to grammaring. Boston: Heinle.

[30] Laufer, B. and Nation, P. (1999). A vocabulary-size test of controlled productive ability. Language Testing, 16(1), 36-55.

[31] Learner autonomy. (2013, April 30). In Wikipedia, The Free Encyclopedia. Retrieved 15:04, August 13, 2014, from http://en.wikipedia.org/w/index.php?title=Learner_autonomy\&oldid=552946719.

[32] Leeven.S. (2010). Calling all proverbs Language Learning Magic, Part III: Proverbs. Retrieved March 13, 2012, from: http://blog.wellreadlife.com/my_weblog/2010/01/calling-all-proverbs-language-learning-magic-part-iii-proverbs.html.

[33] Levine. S. (2003). Student and instructor beliefs and attitudes about target language use, first language use, and anxiety: report of a questionnaire study. The Modern Language Journal, 87, 343-364.

[34] Lotphy. M and Hassanin. H. (1874). Al Touhfa Al Baheyah Fi Al Lughatain Al Inkelizya wa Al Arabya. Cairo: P. Cumbo printing

[35] Ludwig, A. (2001). Historical Dictionary of Islam. Lanham, Md.: Scarecrow Press.

[36] Mihri. M. (1899). Al Touhfa Al Baheyah Fi Al Lughaat Al Inkelizya wa Al Arabya wa Al Fransaweeyah wa Al Turkyyah. Constantinople: dar sa'adat.

[37] Mollaei. F. and Rahnama. H. (2012). Experiential Education Contributing to Language Learning. International Journal of Humanities and Social Science, 2 (21), 268-279.

[38] Morrow. M. (1992). The impact of a literature-based program on literacy achievement, use of literature, and attitudes of children from minority backgrounds. Reading Research Quarterly, 27(3), 251-275.

[39] Muhammad Abduh. (2014, July 24). In Wikipedia, The Free Encyclopedia. Retrieved 14:46, August 13, 2014, from http://en.wikipedia.org/w/index.php?title=Muhammad_Abduh\&oldid=618235442.

[40] Nation, I.S.P. (1990). Teaching and learning vocabulary. New York: Newbury House.

[41] Nazary. M. (2008). The role of 11 in 12 acquisition: attitudes of Iranian university students. Novitas-ROYAL, 2 (2), $138-153$.

[42] Pring, C. (2011). Extensive Reading. [Online PowerPoint presentation], Retrieved May22, 2014, from: http://www.slideshare.net/jcramos175/extensive-reading.

[43] Reda. R. (2006). History of AL Ustaz Al Imam. $2^{\text {nd }}$ edition. Cairo: Dar Al Fadhilah.

[44] Remedia. P. (2007). Practical Practice Reading: Ads \& Coupons. Scottsdale: Remedia Publications.

[45] Richards. J. (2001). Curriculum development in language teaching. Cambridge: Cambridge University Press.

[46] Richards, J. \& Rodgers. S. (2005). Approaches and Methods in Language Teaching. (Second. Edition). Cambridge: Cambridge University Press.

[47] Rybak. S. (1980). Learning Languages from the BBC. Research into Courses for Adults. A report for the British Broadcasting Corporation. ERIC Document No. 195774

[48] Safar Al-Hawali. (2014). In Wikipedia, the Free Encyclopedia. Retrieved 20:32, May 21, 2014, from http://en.wikipedia.org/w/index.php?title=Safar_Al-Hawali\&oldid=609398571. 
[49] Salman al-Ouda. (2014). In Wikipedia, the Free Encyclopedia. Retrieved 20:22, May 21, 2014, from http://en. wikipedia.org/w/index.php?title=Salman_al-Ouda\&oldid=606991441.

[50] Savignon. S. (1983). Communicative Competence: theory and classroom practice. Reading: Addison-Wesley

[51] Schmitt. N. (1997). Vocabulary learning strategies. In Schmitt, N. and McCarthy, M. (Eds.), Vocabulary: description, acquisition and pedagogy (pp. 199-228). Cambridge: Cambridge University Press.

[52] Schmitt. N. and Schmitt. D. (1995). Vocabulary notebooks: theoretical underpinnings and practical suggestions. English Language Teaching Journal, 49(2), 133-43.

[53] Schweers. W. (1999). Using L1 in the L2 classroom. English Teaching Forum, 37(2), 6-9.

[54] Thanasoulas. D. (2010). The changing winds and shifting sands of the history of English Language Teaching. Retrieved June 17, 2012, from: http://www.englishclub.com/tefl-articles/history-english-language-teaching.htm.

[55] Tracey. K. (1998, February). Discourse analysis in communication. Paper presented at the meeting of the Western States Communication Association, Denver.

[56] Walters. J and Bozkurt. N. (2009). The effect of keeping vocabulary notebooks on vocabulary acquisition. Language Teaching Research 13, (4), 403-423.

[57] West. M. (1926). The New Method Readers (New Series) for Teaching English Reading to Foreign Children. Reader 1B. Calcutta, Longmans, Green.

Antar S. Abdellah is an associate professor of TEFL at the Department of Curricula and Instruction, Qena College of Education, South Valley University in Egypt. He received his MA in Linguistics and Translation Theory from the University of London and his $\mathrm{PhD}$ in Education from South Valley University. He published some books on translation and translation pedagogy. He taught language courses in Egypt, Saudi Arabia and the UK. 